\title{
Entre estigmas e afetos: a experiência escolar de jovens em uma periferia de Curitiba-PR
}

\author{
KAMILLE BRESCANSIN MATTAR \\ UNIVERSIDADE FEDERAL DO PARANÁ (UFPR), CURITIBA/PR, BRASIL \\ HTTPS://ORCID.ORG/0000-0002-8873-727I
}

MARIA TARCISA SILVA BEGA

UNIVERSIDADE FEDERAL DO PARANÁ (UFPR), CURITIBA/PR, BRASIL

HTTPS://ORCID.ORG/OOOO-0003-4330-8454

Narrativas sobre a escola e a educação são constantes no cotidiano: seja nas conversas de vizinhança, entre familiares e amigos, seja nas campanhas político-partidárias e nos telejornais, é difícil encontrar alguém que não tenha uma opinião sobre o tema. No entanto, para além das meras conversas corriqueiras, afinal, como os próprios jovens compreendem a escola? Este artigo busca respostas a essa questão, a partir de pesquisa empírica realizada em um Colégio Estadual no bairro Uberaba, em Curitiba (Paraná), entre abril e julho de $2018^{1}$. O objetivo central é observar como os jovens constroem e atribuem sentidos às suas práticas, relações e vivências no ambiente que é a escola. Dessa forma, nosso objeto de pesquisa se refere às interações as quais esse grupo, que são os estudantes, integram. No entanto, o elemento que norteia a análise parte do questionamento sobre as implicações do espaço urbano e suas qualificações nessas interações. Explica-se: estamos preocupadas em compreender se e em que medida a condição de periferia da região interfere ou integra as experiências escolares dos estudantes. Dito isso, dois conceitos são essenciais: o território e a experiência. Os sentidos dados às interações serão abordados a partir da concepção de experiência; a condição de periferia será trabalhada a partir do efeito que o território exerce nessa valoração.

$1 \mathrm{O}$ artigo decorre de dissertação intitulada Entre Vilas: A sociabilidade juvenil como produtora de sentidos em um Colégio na periferia de Curitiba (Mattar 2019). Nessa pesquisa, foram acompanhadas semanalmente as aulas das turmas de $1^{\circ}, 2^{\circ}$ e $3^{\circ}$ anos do Ensino Médio, principalmente nas disciplinas de Sociologia e Educação Física. Outras disciplinas e atividades foram acompanhadas esporadicamente, a depender, respectivamente, da permissão e proximidade com professores e da proposição de passeios, experimentos de Física dentro e fora da escola, conselho de classe, reuniões com pais e/ou responsáveis, entrega de boletim, entre outras. 
Como "experiência" consideramos a maneira pela qual os jovens constroem o mundo, subjetiva e cognitivamente. Ou seja, tanto a partir das representações do mundo vivido, individual e coletivo quanto da percepção cognitiva do real, por meio de um trabalho reflexivo "dos indivíduos que julgam sua experiência e a redefinem" (Wautier 2003: 181). Sendo assim, considera-se que essa construção é relacional. Por isso, o objeto de análise se volta para as interações - especialmente àquelas que se referem aos estudantes e às quais eles integram ativamente -, ocorridas no interior e com o Colégio.

A dimensão espacial das relações sociais - que integra nossa hipótese - se justifica a partir do conceito de "território". Defende-se que a localização das escolas no espaço urbano é um dos fatores que moldam as experiências individuais e de grupos, repercutindo, inclusive, na interpretação e atribuição de significados à realidade de tais instituições e dos próprios sujeitos ali inseridos. Ou seja, além da ação do indivíduo, o espaço em que a escola está situada também importa, sobretudo porque essa noção não se restringe ao substrato material, mas abarca a dimensão dos valores, sentidos e significados atribuídos ao local (Santos 2006). Ainda, tal dimensão valorativa não se institui sem tensões, tendo em vista que, por ser resultado de processos sócio-históricos, a produção dos espaços da cidade está imbricada em relações de poder (Santos 2005, Lefebvre 2006 [1974]). Por isso, não se trata apenas de um mero espaço urbano, mas um "território" e em como este exerce certo efeito nas dinâmicas das relações e interações dos estudantes na e com a escola.

Autores como Andrade e Silveira (2013: 381) abordam tal condição a partir do conceito de "efeito-território", o qual é definido "como os benefícios ou prejuízos socioeconômicos que acometem alguns grupos sociais em função da sua localização no espaço social das cidades”. O que não implica assumir condição e ação deterministas do espaço e das condições materiais sobre as relações sociais, mas propõe um caminho investigativo sobre as inter-relações entre as características dos espaços urbanos (infraestrutura, oferta de bens e serviços, vizinhança) e as características dos grupos sociais e, ainda, como tais condições repercutem ou não nas formas de viver. É esse último ponto que nos interessa, mais especificamente, no que diz respeito às dinâmicas escolares em espaços considerados como de periferia.

Vale evidenciar que a noção de "periferia" surge neste trabalho e decorre de um tensionamento. De um lado, de significações próximas ao senso comum, em que sua representação está habitualmente atrelada a uma perspectiva dominante (e estereotipada) desses territórios e seus habitantes, muitas vezes partindo da pobreza, da carência e da precariedade, para desqualificá-los e colocá-los como subalternos (Feltran 2010). Nesse sentido, este último autor justifica que essas visões estereotipadas também integram e operam o território das periferias, tornando-se elementos discursivos e de práticas que, manejados, marcam diferenças, dinâmicas e sociabilidades locais, por isso, integram nossas análises. $\mathrm{O}$ que não significa a assunção dessas condições como recursos explicativos suficientes e satisfatórios, mas como ponto e contraponto de observação da forma como surgem nas práticas cotidianas desses atores.

De outro, na tentativa de fugir de análises essencialistas, buscamos tensionar e abranger os significados de periferia a partir das práticas sociais em que concepções sobre o território aparecem. Dessa forma, considera-se a ambivalência e complexidade no/do mundo social, observando a mobilidade da categoria a depender dos contextos, situações e interações em que é manejada pelos atores sociais. 
O que nos interessa nessa discussão, portanto, é compreender como o vínculo entre o território e a população ali residente a um conjunto de significados valorativos opera no ambiente escolar. Especificamente, como esse conjunto de significados adentra o ambiente da escola e integra a experiência desses estudantes.

Para tanto, esse trabalho está organizado em três momentos. No primeiro, será apresentada a caracterização da pesquisa, principalmente em razão do território em que o Colégio está inserido e do referencial teórico utilizado para pensar sobre o bairro. Nos dois tópicos seguintes, a proposta de análise é desenvolvida, primeiro a partir da noção de "estigma" de Goffman (1982) e, em seguida, a partir dos conceitos de "afetos" e "afetividade" (Le Breton 2012). Com "estigma”, pretendeu-se articular a caracterização da região e das Vilas ao redor do Colégio com categorias nativas de qualificação dos estudantes, em que os próprios se diferenciam entre boyzinho e mimado, favelado e maloqueiro, além de bandido. Neste momento, argumenta-se que tais qualificações decorrem da condição territorial e social em que o Colégio está, a qual é cotidianamente reconhecida enquanto periferia.

Já a concepção de "afetos" surge a partir do interesse em discutir a condição juvenil dos estudantes e suas formas de subjetividade. De tal forma que se torna, em nossa perspectiva, elemento constitutivo da rede de sociabilidade deles enquanto jovens e da atribuição de sentido ao espaço escolar. Por serem dotados de significados, consideramos que os afetos manejados pelos estudantes estão vinculados a um sistema de valor atrelado tanto à condição juvenil, quanto à condição territorial. Nesse sentido, para abordar as relações e interações estabelecidas entre eles dentro do Colégio, propomos discorrer sobre como as paqueras, as brigas e os confrontos, assim como a tecnologia, são mobilizados.

Por isso, o interesse em olhar para a escola a partir da perspectiva do efeito do território (Andrade e Silveira 2013), buscando evidenciar as relações e interações sociais que nela ocorrem e como estas interferem nas interpretações sobre a experiência social dos atores envolvidos, em nosso caso, os estudantes. Nessa perspectiva, como argumento central, defende-se que essa experiência, de um lado, é estigmatizada, pois estendem-se aos estudantes as marcas de distinção e marginalização impostas social e territorialmente às Vilas em que moram, estudam e vivem cotidianamente; de outro, é afetiva, pois está imersa numa trama de significados decorrentes da rede de sociabilidade e afetos dos estudantes dentro da escola.

\section{A caracterização da pesquisa: as fronteiras, o colégio e as vilas}

No ano de 2018, em que foi realizado o trabalho de campo, o Colégio pesquisado contava com 632 estudantes matriculados, distribuídos entre Ensino Fundamental - EF (12 turmas), Ensino Médio Regular - EM (06 turmas) e Educação de Jovens e Adultos - EJA (02 turmas), nos turnos matutino ( $9^{\circ}$ ano do EF ao $3^{\circ}$ ano do EM), vespertino $\left(6^{\circ}\right.$ ao $8^{\circ}$ ano do EF) e noturno (EJA, EF e EM). Somente no Médio Regular, série de ensino de nosso interesse, eram 191 estudantes ${ }^{2}$. Do total de matrículas,

2 Dados disponibilizados pelo Setor de Disseminação de Informações Educacionais e elaborados pela Superintendência da Educação, Diretoria de Assistência a Projetos da Educação e Centro de Informações Educacionais (SUED/DIRPE/CIE), da Secretaria de Estado da Educação do Paraná (SEED-PR). 
179 tinham famílias cadastradas no Programa Bolsa Família ${ }^{3}$, ou seja, 28,32\% ${ }^{4}$; além disso, pelo menos quatro apresentavam necessidades especiais, como surdez, déficit cognitivo grave e déficit motor ${ }^{5}$.

A equipe escolar era composta de: uma diretora (mulher), 42 professores $^{6}$, cinco pedagogas (todas mulheres), seis funcionários administrativos da secretaria (entre homens e mulheres), uma bibliotecária (mulher) e nove profissionais de serviços gerais (limpeza, jardinagem e cozinha; com a prevalência de mulheres ocupando tais cargos $)^{7}$. Ainda, havia um caseiro que morava no terreno atrás do Colégio, sendo responsável por sua manutenção e segurança quando este estivesse vazio, além do capelão, que atuava voluntariamente, em conjunto com a atividade das pedagogas. De forma geral, considerando o número de matrículas, o Colégio pode ser considerado de estrutura e tamanho médios ${ }^{8}$.

Em termos geográficos, o Colégio localiza-se na borda do bairro Uberaba, quase na divisa com o Boqueirão, bairro vizinho, e se mistura com as grandes lojas de departamento, as avenidas de trânsito rápido e os comércios locais. Não é difícil perceber a mudança de paisagem na passagem de um bairro a outro, em que "os prédios altos e comerciais dão lugar aos comércios de vizinhança e às áreas residenciais e se intercalam entre condomínios fechados recém-construídos e casas, às vezes de alvenaria, às vezes de madeira" (Mattar 2019: 59). Essas divisas também vão, aos poucos, se apresentando física e verbalmente em relação ao próprio bairro em que o Colégio está inserido: os caminhos do trilho do trem, a Rodovia BR-277, as Avenidas das Torres e Salgado Filho, os canais dos rios Belém e Iguaçu, "que ao cortar e contornar o bairro, delimitam suas fronteiras internas e externas" (ibidem).

Essas fronteiras, muitas vezes, ao delimitarem o entorno, instigam uma oposição e uma dualidade entre noções de "um dentro" e "um fora", o que é defendido por Mayol (2013 [1994]) como o elemento definidor da noção de bairro. O autor está preocupado acerca de como a forma de uso cotidiano do bairro transforma aquele espaço urbano em algo conhecido, em que os indivíduos se sentem reconhecidos, positiva ou negativamente. Essa situação proporcionaria apropriações subjetivas sobre bairro, a partir da progressiva aprendizagem sobre aquele espaço. Aprendizagem que "vai progredindo mediante a repetição do engajamento do corpo do usuário no espaço público" (Mayol 2013 [1994]: 40). Trata-se, em outros termos, de considerar as marcas impostas pelos usuários ao espaço do bairro por meio do seu uso cotidiano e habitual.

Desde 1890, quando predominavam no bairro em foco as plantações de subsistência e a atividade agropecuária, a Avenida Salgado Filho, à época estrada de acesso ao município vizinho de São

\footnotetext{
3 Programa Social implementado pelo Governo Federal, em 2003. Visa ao combate da pobreza e da desigualdade por intermédio da transferência de renda, atuando pela articulação de políticas públicas. Por isso, uma das condicionalidades para cadastro é a matrícula dos dependentes em instituições de ensino.

4 Para fins de comparação, em outros dois Colégios onde também realizamos trabalho de campo, nos bairros Portão e Cidade Industrial, essa taxa é, respectivamente, de 4,54\% e 18,8\%. Os dados são de 2018 e foram disponibilizados pela SEED/SUED/DIRPE/CIE - Disseminação de Informações Educacionais.

5 Dados obtidos por meio da pesquisa empírica, contabilizados em razão das relações estabelecidas, por isso, não representam um número fechado, mas sim uma amostra parcial.

6 Dados informados pela SEED/SUED/DIRPE/CIE - Disseminação de Informações Educacionais.

7 Exceto o número de professores, os demais dados foram obtidos por consulta ao Projeto Político Pedagógico (PPP) de 2018.

8 Levando em conta que, no ano de 2018, entre os 134 colégios estaduais da cidade que ofertavam o Ensino Médio, o número de matrículas variava entre 77 e 3.837 alunos.
} 
José dos Pinhais, era um importante eixo de escoamento de rebanhos, configurando-se como uma das divisas importantes da região, entre as implantações do alto e do baixo Uberaba (Mattar 2019; Belmiro 2019). Delimitações que, apesar de sofrerem algumas alterações, constituem até hoje elementos de referência sobre as fronteiras do bairro, que habitualmente é divido pelos seus moradores entre Uberaba de cima e Uberaba de baixo, ainda em referência à mesma avenida (Brandalize 2017; Belmiro 2019).

Essas demarcações, a despeito de nem sempre coincidirem com os limites apresentados pelos indivíduos dentro do Colégio durante o período de trabalho de campo, certamente refletem a história de um bairro separado e recortado, de maneira que as delimitações entre acima ou abaixo do rio, por exemplo, são referências cotidianas de todos os atores escolares ao se referirem aos canais fluviais do Rio Belém. Estes são utilizados tanto para indicar o local e a distância da residência dos estudantes em relação ao Colégio quanto para apresentar e qualificar as regiões próximas.

É a partir do uso habitual, no caso exemplar dos canais, que se promove o que Mayol (2013 [1994]) chama de a privatização progressiva do espaço público, em que se cria a noção de continuidade entre aquilo que é o mais íntimo, a casa e o desconhecido, a rua. De onde surge a relação entre o "dentro" e o "fora" do bairro, à medida que este é apropriado pelos indivíduos. O bairro é, assim, atravessado pelo limite entre o espaço público e o privado, tendo em vista que, muitas vezes, torna-se o prolongamento da habitação, constituindo-se, como relembram Magnani (2003) e Pereira (2010), o espaço intermediário entre a rua e a casa. Nesse sentido, o bairro é o lugar de uma relação com o outro como ser social, assim, "sair de casa, andar pela rua, [...] inscreve o habitante em uma rede de sinais sociais que lhe são preexistentes (os vizinhos, a configuração dos lugares, etc.)” (Mayol 2013 [1994]: 41).

O Colégio está inserido nessa "rede de sinais" de tal forma que suas relações internas também carregam os códigos e as marcas do bairro. Dos estudantes, a maioria não apenas é residente do bairro, mas das Vilas, regiões administrativas menores, que cercam o Colégio ${ }^{9}$. Já o corpo docente, o grupo pedagógico e administrativo (diretores, funcionários da limpeza e da secretaria), muitos têm ou tiveram relações estreitas com o bairro: uns são moradores e outros moraram durante a infância e adolescência e, apesar de terem mudado de local de residência, continuam a ter familiares e frequentam a região. Dessa forma, não é de se estranhar que as dinâmicas, relações e os valores do bairro adentrem e constituam também as dinâmicas, relações e os valores dentro do Colégio.

Não é à toa, nos arredores e corredores do Colégio, a constante e recorrente referência às Vilas ${ }^{10}$ da região, as quais, mais do que uma menção a uma demarcação administrativa feita pela Prefeitura do Município, cristalizam uma forma de qualificação, valoração e/ou identificação dos seus habitantes, interações e modos de viver cotidianos. Nesse sentido, o conhecimento sobre os lugares, os trajetos do dia a dia, as relações de vizinhança e com os comerciantes, os sentimentos sobre o território, todos esses são

9 Vale pontuar que, habitualmente, a denominação das Vilas resulta do processo de loteamento dos territórios realizadas pelos próprios moradores. Dessa forma, não obedecem, a rigor, definições formais-legais, apesar de incorporadas, posteriormente, pelas políticas públicas e transformadas em delimitações administrativas do município. Esse processo de regulamentação e incorporação dos lotes tanto aos mercados imobiliários formais quanto ao processo de urbanização da cidade é tratado por Belmiro (2019), a partir da experiência coletiva da Vila União Ferroviária, na região conhecida como Bolsão Audi-União, no bairro do Uberaba, em Curitiba (Belmiro 2019; Belmiro, Bega 2018).

10 Ao nos referirmos às Vilas da região em itálico, temos a pretensão de distinguir a concepção de "Vila" enquanto demarcação administrativa oriunda (e apropriada) pela Prefeitura Municipal em relação à forma como os atores sociais da região, principalmente, os estudantes, se referem a territórios específicos em torno do Colégio, resgatando e enfatizando esta segunda forma. 
elementos que produzem e organizam o dispositivo cultural e social segundo o qual "o espaço urbano se torna não somente objeto de um conhecimento, mas o lugar de um reconhecimento" (Mayol 2013 [1994]: 43, grifo do autor). É, sobretudo, uma forma de conhecer, apresentar e se inserir nos sistemas de valores e redes de relações da região.

Segundo os estudantes, o Colégio fica na divisa entre três Vilas: Lorena, Meia Lua e Cidade de Deus (CDD), reunindo jovens dessas três localidades.

\section{Imagem 1: Localização do Colégio no B. Uberaba e Vilas - I}

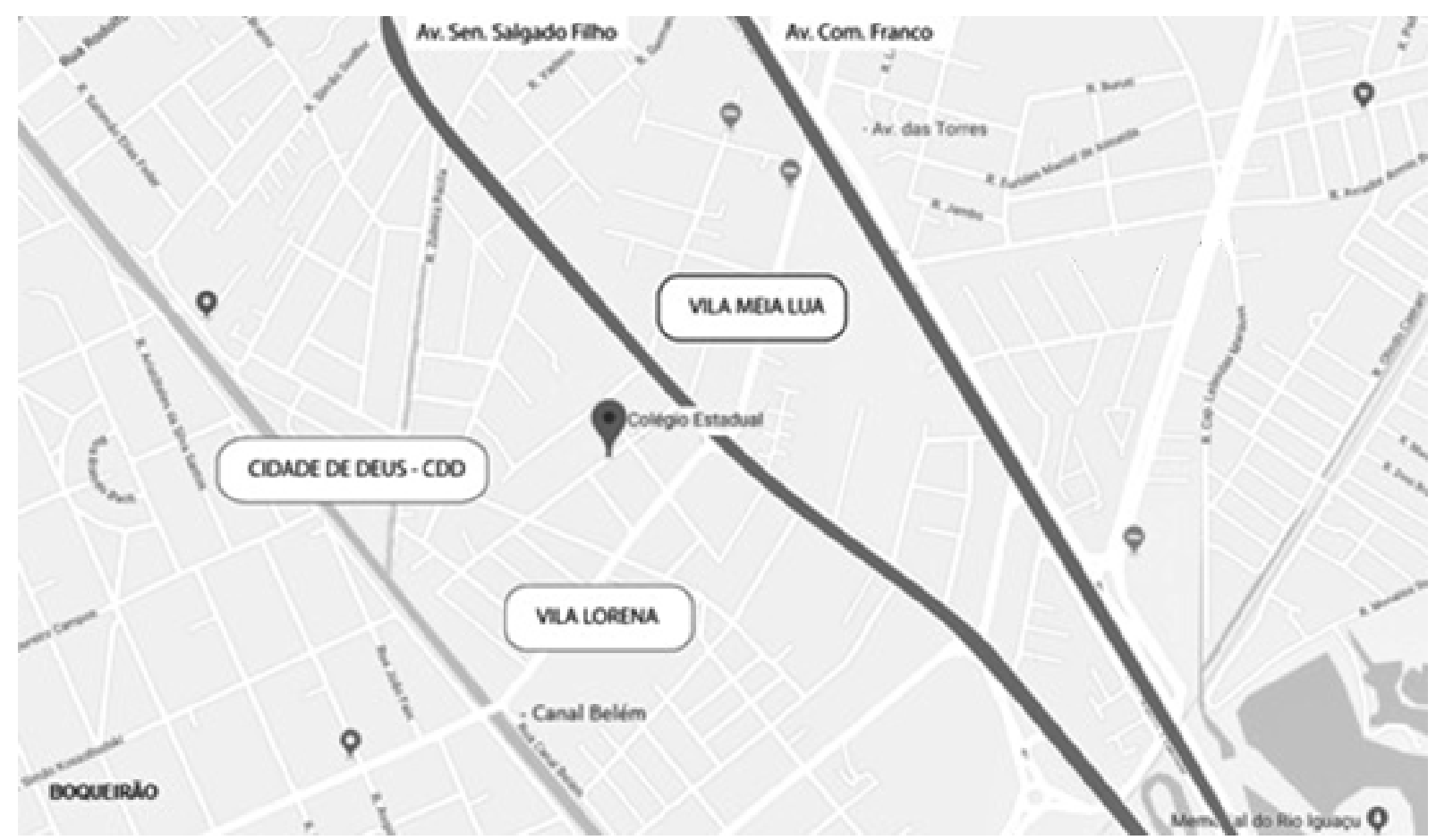

Fonte da imagem: Mattar, adaptado do Google Maps, 2019.

A diferença entre as Vilas está longe de fazer menção apenas à infraestrutura e distância ao Colégio. A cada coordenada de sua localização, os estudantes adicionam uma série de atribuições e valorações, as quais variam entre considerações sobre o grau de periculosidade e violência da região; a existência de pontos de venda de drogas; a referência a locais de trabalhos dos familiares, residência de amigos ou a outros estabelecimentos tidos por eles como pontos importantes, como o bar do Vitor, ao lado do mercadinho, e a pastelaria próxima ao posto, onde um dado colega trabalha; a condição das casas da região, em que há a diferenciação entre os sobrados, condomínios e as casinhas da Cohab ${ }^{11}$, ou ainda dicas, conselhos e avisos sobre os trajetos e caminhos a serem evitados ou possíveis de passagem, tendo em vista que éramos consideradas como de fora.

Todos esses referenciais explicitam o uso habitual do bairro, o que também implica o conhecimento sobre um sistema de valor, constituído por códigos de linguagem e comportamentos, posto ser uma convenção coletiva tácita, não escrita, mas conhecida e legível por todos, em que a submissão ou transgressão se torna passível de comentários e olhares (Mayol 2013 [1994]). Mas as sinalizações

11 É o modo como boa parte dos estudantes faz referência às moradias decorrentes do Programa Minha Casa Minha Vida, implementado pela Companhia de Habitação Popular em Curitiba (COHAB). 
espaciais também evidenciam as demarcações e fronteiras internas que, a nosso ver, repercutem nas qualificações e valorações entre esses territórios e seus habitantes dentro do Colégio.

De modo geral, quando tratamos a cidade enquanto espaço social tem-se a pretensão de referenciar essas condições, em que as concepções sobre as regiões e suas localidades sofrem influência das dinâmicas sociais que estão ali inseridas (Schmid 2012; Lefebvre 2006 [1974]). Nesse sentido, o que autores como Caldeira (2011), Kowarick (2009) e Silva (2014) defendem é que o local de moradia, além de não estar restrito a uma condição geográfica, reflete um processo de exclusão e discriminação social, em razão do modelo da urbanização brasileira.

Silva (2014) argumenta que o modelo de ocupação territorial brasileiro decorre do processo em que as atividades industriais e comerciais estão concentradas nos centros urbanos, e a população de baixa renda é redistribuída para as periferias precárias, distantes da metrópole, o que constitui o padrão “centro-periferia” de urbanização, característico principalmente até a década de 1980 (Belmiro 2019; Caldeira 2011; Kowarick 2009). Esse movimento é responsável pelo que chama de "periferização da pobreza" e está intrinsecamente relacionado ao regulamento do loteamento de terras e ao enriquecimento dos terrenos, repercutindo na valorização das áreas centrais e não deixando alternativa para os mais pobres além da migração/ocupação das áreas mais distantes, menos valorizadas e em piores condições de infraestrutura e moradia (Belmiro 2019, Kowarick 2009, Santos 2017). O aparecimento das favelas e cortiços, a partir da década de 1960, se remete a esse processo.

No entanto, junto com a concentração da pobreza e das condições precárias, esses lugares carregam marcas valorativas negativas (Santos 2017), que podem se estender à estigmatização e discriminação de seus moradores (Goffman 1982) e às formas de gestão dos espaços urbanos. Segundo Telles (2015), os conflitos que se colocam no e pelo espaço urbano se desdobram em torno do ordenamento e agenciamento desse "urbano" e seus dispositivos de poder. Em processos mais recentes, ações de urbanização das favelas e periferias, como a gentrificação, por exemplo, podem ser vistas como processos de expansão metropolitana, mas também enquanto ampliação das fronteiras de mercado. Em consequência, as lógicas e os circuitos mercadológicos se estendem aos modos de vida e de habitar a cidade, produzindo formas de controle da gestão desses espaços. O que nos interessa é ressaltar a cidade enquanto espaço produzido a partir de dispositivos e relações de poder e, por isso, constituída por "territórios" (Santos 2005; Lefebvre 2006 [1974]; Telles 2015).

De forma que o território (e a cidade) é uma produção, resultado de processo histórico, de base material e social das ações humanas. Com isso, busca-se entender quais as implicações dessa distribuição que, em um primeiro momento, utiliza-se de condições aparentemente geográficas - "centro-periferia” -, para evidenciar a carga valorativa das dinâmicas sociais que estão inseridas nessas condições. Logo, o que significa esse "centro" e essa "periferia" e como essas concepções foram construídas no processo de formação da cidade.

Dito isso, de um lado, não é viável desconsiderar as marcas e cargas valorativas que a desigualdade das condições materiais impõe à vida cotidiana, constituindo-se em elemento tanto de reprodução de iniquidades e visões estereotipadas quanto de mobilização dos próprios atores sociais a que 
são impostas (Feltran 2010). Isso porque a categoria de "periferia", como já discutido de início, não é suficiente em si mesma, mas está inserida em um processo urbano de produção das cidades brasileiras.

De outro lado, é importante dimensionar que há compreensões sobre essa categoria que não advêm apenas de uma oposição binária e polarizada com o "centro", mas como um espaço social de dinâmicas próprias (Frúgoli Jr. 2005; Durham 2004 [1986]). Magnani (2003) e Pereira (2010) apontam, respectivamente, como no discurso dos rappers e pichadores de São Paulo (SP) a concepção de periferia mobilizada, muitas vezes, enfatiza mais o pertencimento e surge enquanto elemento de afirmação e superação que de carência. A partir disso, os autores propõem outras categorias sobre o espaço urbano, como "pedaço" e "quebrada”, para compreender a ambivalência e complexidade das interações sociais na cidade. Nesse sentido, mais que um espaço social, propomos aqui um olhar sobre a cidade a partir dos territórios que a compõem e dos sentidos que, ao serem tratados como "periferia", "centro", "quebrada”, "vila”, etc., podem assumir.

Por isso, "centro" e "periferia" são tomados aqui como categorias relacionais, com tensões e aproximações. Assim, nosso interesse recai em olhar para a escola e para a cidade a partir da perspectiva do "território" (Andrade, Silveira 2013), questionando qual o efeito que este exerce na experiência social dos atores envolvidos em determinado espaço, considerando as condições e estruturas de desigualdades sociais impostas a eles, mas também como e quando essas categorias são mobilizadas e manejadas pelos sujeitos sociais. Em nosso caso, temos os estudantes de uma escola pública e a forma como constroem sua experiência nessa instituição como foco.

\section{Entre as vilas e o colégio: $\mathrm{O}$ estigma que se estende aos estudantes}

Além das próprias configurações internas, há condições externas que se constituem enquanto elementos que pautam e qualificam as relações e os convívios cotidianos no Colégio, especialmente aquelas atribuídas a alguma das Vilas próximas. Neste tópico, pretendemos abordar esse conjunto de elementos, buscando observar como o território em que o Colégio está adentra esse espaço escolar.

Logo em um dos primeiros dias frequentando a instituição em tela, já fomos apresentadas a uma série de atribuições da região, em que aparecem as qualificações sobre o que é considerado perto, longe, a presença do limite com o bairro vizinho e, o mais importante, a dificuldade e o receio em se falar sobre o tema (Mattar 2019). Situação que muitas vezes aparece como forma de não dizer exatamente onde se mora, substituindo a precisão da localização pela justificativa de que se pode ir andando ao Colégio, que não se chega a morar no bairro limítrofe do Boqueirão ou, ainda, na fala de um sujeito de pesquisa, que "venho de lá, mas do lado de cá do rio".

Às sete horas e 30 minutos, quando os estudantes estão chegando ou ao final do turno da manhã, às 11 horas e 50 minutos, é possível perceber que a maioria vai e volta a pé a suas casas, normalmente se aglomerando em grupos em razão da direção em que se localizam as residências. Por isso, não é de se espantar que as dimensões do quanto é longe ou perto sejam associadas ao tempo de uma caminhada. 
A caminhada, muitas vezes, também aparece como algo mais que um marcador temporal, emergindo como indicador da relação com o bairro e entre os próprios estudantes.

Ir a pé é o meio empregado pela grande maioria dos estudantes para frequentar as aulas, e qualquer situação ou possibilidade de deslocar-se de outra forma impacta em comentários entre eles. Ir de carro é uma grande mordomia que, além de exaltar certas condições materiais, evidencia a disponibilidade dos pais ou responsáveis em fazer isso. Isso se expressa em comentários como o seguinte: "Nossa, teu pai até te traz pro Colégio, é muito mimada!" (Mattar 2019). Tal frase, quando dita, não passa despercebida e, dependendo com quem a interação está sendo feita, pode soar como uma brincadeira entre amigos ou uma ofensa, causando até mesmo alguma discussão mais acalorada. De forma que ir até o Colégio, as maneiras de se ir e de onde se vem constituem algo mais que a forma de chegar à escola. Trata-se de um elemento que, ao ser manejado pelos estudantes, nos trazem indícios sobre a relação entre o Colégio e o bairro.

Nesse sentido, as Vilas aparecem no interior do Colégio, não apenas para indicar o local de residência, mas para instituir marcas e qualificações sobre os estudantes e sobre a própria escola. Diferente das demais Vilas, cuja denominação é assumida pelos órgãos públicos, a menção à CDD aparece como um "apelido" valorativo atribuído pelos estudantes, o qual eles mesmos associam e explicam: Cidade de Deus, igual ao filme. Remete-se, assim, a uma produção cinematográfica nacional lançada em 2002, sobre a realidade de dois jovens em uma favela carioca nos anos 1970.

Talvez não por mera coincidência, a CDD é também associada às áreas mais pobres, perigosas e violentas da região, principalmente, pela existência de pontos de venda de drogas. Nesse sentido, a caracterizam como um lugar de dar medo, em que "teria pobre mesmo", buscando distanciá-la das áreas ao redor do Colégio que, apesar de também serem reconhecidas como regiões pobres, não são atreladas à venda de drogas e à existência de armas de fogos ou ainda à presença de habitações do Programa Minha Casa Minha Vida ${ }^{12}$, construídas pela Cohab, como ocorreria na Vila em questão.

A Vila Lorena, a despeito de não se equiparar às qualificações da CDD, também é caracterizada por condições de pobreza e casas mais simples, mas morar nessa vila não causa constrangimentos aos estudantes, que não parecem ter problemas em dizê-lo. Já a Vila Meia Lua é qualificada como tendo as melhores condições de moradia e, coincidentemente ou não, pouco se fala dela.

De certa forma, as condições de pobreza e marginalidade mobilizadas para qualificar algumas das regiões próximas podem ser associadas à desqualificação recorrente do Colégio pelos próprios estudantes, os quais afirmam que só estudam ali por ser a instituição mais próxima de suas casas, "por falta de opção" ou ainda expressam desdém quando questionados sobre a continuidade da matrícula no próximo semestre. O desprezo pelo Colégio é evidenciado, muitas vezes, pela forma como os estudantes se referem "àquela” realidade, ao enfatizarem que na referida escola os colegas não querem saber de nada ou que a instituição é muito ruim. Como se os problemas enfrentados ali cotidianamente fossem inexistentes em outros Colégio e não decorressem da existência e execução de uma série de políticas públicas direcionadas ao sistema educacional do Estado.

12 Programa Social desenvolvido pelo Governo Federal e executado em parceria com Estados, municípios, empresas e movimentos sociais. Visa a facilitar e até mesmo subsidiar as condições de acesso a um imóvel por meio de financiamento facilitado. 
Apesar do tom de $z$ oeira ${ }^{13}$, as piadas sobre a qualidade da merenda servida durante o intervalo são exemplificadoras desta condição, em que, ao brincarem com os nomes das empresas fornecedoras dos alimentos, enfatizam que, diferente de outras escolas, ali só pode ser a pobrelândia (Mattar 2019). O que chama atenção na piada não é a ênfase na condição de pobreza atrelada ao Colégio, mas principalmente o menosprezo dos próprios alunos ao tratar dessa condição. Ser pobre e estar em uma região pobre aparece aqui como justificativa e marcador pelo fato tanto da comida ser ruim quanto de uma suposta má qualidade de ensino ou, ainda, diante do desinteresse dos estudantes que frequentam a escola.

Dessa forma, mais que considerar as desigualdades e carências materiais em suas narrativas, como é o caso das piadas, há outros significados que emergem dessas qualificações sobre o Colégio. Recorrentemente, são mobilizadas pelos próprios estudantes ao atribuírem a condição de favelado e maloqueiro a certos grupos e de boyzinho ou mimado a outros, adjetivações que parecem repercutir nas interpretações sobre o Colégio e em estigmas aos alunos.

As categorias boyzinho e mimado apareceram atreladas a certas facilidades tanto financeiras e materiais quanto nas relações familiares. Em um dos casos, as brincadeiras e cobranças implícitas sobre essa condição surgem pouco antes do intervalo, em razão de um garoto de um grupo de amigos ter levado um pacote de salgadinho de uma marca reconhecida. O que desencadeou comentários como "é muito boyzinho", seguido, de um lado, da troca de olhares entre os colegas em busca da confirmação mútua sobre o dito; de outro, da recusa e do constrangimento do garoto em aceitar a condição. Para argumentar a respeito e reforçá-la, os amigos, inclusive, frisam que ele também compra refrigerante na padaria, estabelecimento em que os produtos seriam bem mais caros. Toda a conversa transcorre em tom de brincadeira e envolta de gargalhadas, situação que, apesar de não desencadear nenhum conflito, por se tratar de um grupo reconhecido de amigos, certamente gera desconforto no dono do petisco, tendo em vista que é o único a permanecer quieto, sem risadas e sem ver graça na situação.

Além dos produtos consumidos no intervalo, outros fatores não passam despercebidos entre os alunos e são utilizados como elementos característicos da condição de boy, como, por exemplo: não precisar trabalhar; permanecer em casa o dia todo; ir de carro para a escola, entre outros. Situações que, quando explicitadas, são imediatamente justificadas pelos estudantes, seja por ajudar a mãe nas tarefas domésticas e nos cuidados com os irmãos mais novos, seja por participar das atividades profissionais informais realizadas pela família, como, por exemplo, a venda de doces feitos em casa.

De um lado, há a justificativa e o desconforto daqueles que recebem tal titulação; de outro, há a provocação e euforia daqueles que passam despercebidos a essa regra. De forma que a condição de boyzinho, mesmo que não se torne uma ofensa grave e não configure razão consistente para uma briga mais séria, é utilizada como marcador dentro do Colégio pelos estudantes por meio da brincadeira, da graça e da piada. Situação bastante diferente de quando os termos favelado e maloqueiro aparecem.

Nesses casos, os comentários se constituem em uma forma de menosprezar os colegas e justificar a baixa qualidade do Colégio, ao afirmarem que certos estudantes "estão nem aí com nada" e que "não

13 Termo utilizado pelos estudantes e mobilizado enquanto categoria analítica por Pereira (2016) para abordar tanto o modo como os próprios jovens se referem às brincadeiras feitas entre eles nas escolas frequentadas quanto à apropriação desse espaço por esses sujeitos a partir de tais interações. Neste trabalho, compartilhamos desse entendimento para as análises seguintes sobre afeto, território e juventude. 
teria como recuperar", pois, estes já saberiam o que seria certo ou errado e, ainda assim, escolhem agir da pior forma. Uma série de elementos constitui essa categoria do favelado ou maloqueiro, a qual, juntamente com a pobreza e irresponsabilidade de comportamento, pode surgir com proximidade ao uso de drogas, principalmente a maconha.

A droga se configura em um diferencial que aproxima estudantes à condição de violência e criminalidade e chega, inclusive, a ser utilizada como elemento para justificar o sentimento de medo de alguns em relação a outros. Mesmo que, durante o período de trabalho de campo, tais condições tenham sido mobilizados apenas discursivamente. Essa articulação entre venda/uso de drogas, violência e criminalidade aparece recorrentemente atrelada a uma das Vilas próximas ao Colégio, a qual é reconhecida justamente a partir desses elementos, conforme já assinalado. Esses referenciais se estendem aos estudantes na medida em que são vistos frequentando tal Vila fora do horário de aula, em quantidades e pontos específicos que indicam no "imaginário social” (Taylor 2010) a relação entre o estudante e as drogas ${ }^{14}$.

Discussões e conflitos entre grupos específicos na sala de aula é acontecimento recorrente e habitual nas turmas, entretanto, em algumas dessas ocasiões, o confronto chega a extrapolar tais paredes e se dirige à coordenação, o que, inevitavelmente, gera uma correria e movimentação pelo pátio e na sala das pedagogas. Em uma dessas ocasióes, dois grupos, um de garotos e outro de garotas, se provocaram a tal ponto que uma acusação de roubo de material e uma ameaça de agressão surgiram e tomaram conta da escola. Dentre as idas e vindas da situação, que incluíram revistar material de todos os estudantes da turma, proibi-los de participar do intervalo e infinitas broncas e ocorrências, o grupo de garotas começou a ficar mais nervoso e discutir entre si.

Isso porque enquanto umas não aguentam mais "sofrer as ameaças" dos garotos, outras pedem insistentemente para que se fale baixo e se interrompam as provocações, querendo acabar com a situação o mais rápido possível. As considerações ganham ou não força e justificativa à medida que outras características são adicionadas à história. No caso das ameaças e do possível perigo que um dado colega apresenta, surge inevitavelmente o fato de, supostamente, usar drogas e ter relações com pessoas específicas fora do Colégio. Quando a narrativa não aparece explícita, como nessa discussão específica, emerge nas entrelinhas, diante da explicação de que "ninguém mexe com eles [os referidos garotos], nem as pedagogas, [...] podem ver, elas nunca brigam com eles" ou, ainda, por meio de um sussurro preocupado, verbalizado na expressão todo mundo sabe.

O que não se confunde, nem está estritamente relacionado aos estudantes que moram na região, tendo em vista que há uma distinção entre os vistos como potenciais ameaças - e vinculados à venda e/ou ao uso de drogas - e aqueles considerados apenas como pobres. Nesta segunda forma, a noção de pobreza aparece, em um primeiro olhar, atrelada à carência e precariedade material, e entre os próprios estudantes surgem falas e comportamentos na tentativa de se afastar dessa condição. Isso porque a falta

$14 \mathrm{O}$ conceito é usado para se referir ao modo habitual como as pessoas "imaginam" sua realidade social que, por ser partilhada entre grupos, possibilita e confere legitimidade a práticas comuns. Assim, abarca mais que um conjunto de ideais, pois implica em normatizações construídas e construtoras a partir desses imaginários (Taylor 2010). 
material se estende a características valoradas negativamente sobre o grupo de discentes, enquanto desinteressados, indisciplinados e marginalizados.

Inclusive, sendo os responsáveis por caracterizar, segundo os próprios colegas, o Colégio como ruim, justamente por não o "aproveitar corretamente" como uma oportunidade de sair de tal condição. De qualquer forma, mesmo quando tentam se distinguir, é a noção do grupo que prevalece, sendo o desinteresse o elemento que une o coletivo de estudantes e do qual individualmente alguns querem se distanciar. Diferentemente dos elementos da droga e do crime, como formas de o grupo marcar e demarcar a especificidade de alguns alunos daquela escola, justamente para diferenciá-lo do todo.

Assim, na narrativa dos estudantes, enquanto a droga é usada como forma de qualificar um ou outro estudante específico, em termos de criminalidade e violência, a pobreza aparece, normalmente, atrelada a um modo geral do grupo se comportar, reforçando noções de que tanto a escola, como a educação são desinteressantes e desvalorizadas. As categorias de favelado, maloqueiro e até mesmo vileiro - esta última surge mais na fala dos professores - emergem para caracterizar os comportamentos dos estudantes, ora para demarcar a diferença entre eles, no caso da droga, ora para constituí-los enquanto grupo unificado, no caso da pobreza. Ambas os caracterizam de forma negativada, a ponto de justificar a precariedade e qualidade "daquele" Colégio.

Ainda, categorias como boyzinho, favelado e maloqueiro evidenciam como as características grupais e individuais são mobilizadas em razão das relações e interações em que estão inseridas. A depender com quem e de que forma, é possível ser classificado em uma ou outra categoria, sendo que a diferenciação ou aproximação com o grupo são elementos constituintes, inclusive para o corpo docente e a direção.

Entre estes, a condição de pobreza, em termos explícitos e verbalizados, é articulada como fator de criminalidade da região. Em muitas ocasiões, a ênfase está no perigo local, de maneira que os mais antigos profissionais do Colégio e que também moram pelos arredores orientam aos novatos que não andem para muito longe e, se o fizerem, não levem os celulares, pois o risco de roubo é grande. Num primeiro olhar, em relação aos estudantes, tal condição aparece ao se referirem à clientela ${ }^{15} \mathrm{da}$ escola, como sendo de jovens periféricos ou da periferia, justamente em razão das condições precárias da região, em termos de oferta de bens e serviços e de renda familiar, justificando para tanto que muitos moram pra lá do rio ${ }^{16}$ ou que não teriam condições de comprar mais de uma peça do uniforme.

De forma que a noção de periferia também fica atrelada e condicionada à carência e falta de condições materiais. Entretanto, mais que isso, as ideias de periferia e pobreza surgem para caracterizar, qualificar e impor condição valorativa aos modos de vida, de ser, falar e se comportar desses estudantes, ao trazerem junto com elas concepções disfarçadas de conselhos sobre a higiene destes em razão de piolhos ou a frequência de lavagem dos uniformes; acerca da capacidade e do interesse no processo de aprendizagem; ou, ainda, sobre uma suposta desvalorização da educação em geral e da própria perspec-

15 Alguns professores usam esse termo para se referirem aos grupos de estudantes, mas não é uma unanimidade. Entretanto, como também é utilizado no PPP, optamos por incluí-la na análise, tendo em vista que nas, ocasiões em que foi usado, referia-se justamente às condições periféricas dos estudantes.

16 Morar para lá do rio, o canal Belém ou na beira dele, implicava habitar uma das regiões mais pobres dos arredores do Colégio, embora não significasse viver nas áreas mais perigosas, que eram atribuídas aos locais em que se cogitava o comércio de drogas. 
tiva de futuro. Essa visão, além de reforçar a concepção de periferia a partir da carência e da falta, traz o julgamento moral sobre as formas de vida e comportamento.

Assim, a pobreza, além de ser muitas vezes articulada a interpretações sobre a caracterização da região como violenta e perigosa para aqueles de fora, recaía sobre os estudantes na constituição de um modo de comportamento, caracterizado e pautado ao redor de concepções de precariedade, falta de recursos e carência, inclusive no que diz respeito à adesão a práticas educacionais e escolares. Ou seja, resultando em estigmatização desses estudantes como desinteressados e irresponsáveis com o cotidiano escolar e as atividades propostas, sem preocupação com o próprio futuro e à mercê das carências materiais da região.

Há ainda outra categoria que surge entre as narrativas e o comportamento dos estudantes, a de bandido, a qual era normalmente articulada como parte do repertório para impressionar, causar medo ou até mesmo compor as zoações dentro da escola, sem que necessariamente haja alguma intenção ou vinculação com qualquer prática criminosa. Pereira (2016) evidencia condição semelhante em colégios da periferia de São Paulo, onde os alunos também mobilizam essa categoria como formas de sociabilidade, acionadas como parte do repertório nas conversas e em comportamentos que visavam a demostrar força e virilidade ou a integrar o jogo da zoeira. A referência a ser bandido aparece ora para impressionar ou causar impacto, ora para confrontar os colegas, que durante alguma discussão em sala também reivindicavam essa condição.

Em uma das aulas acompanhadas, o termo surgiu nesse sentido em razão de uma briga entre estudantes por causa do excesso de conversa e barulho em sala. Um deles estava interessado em fazer perguntas para o professor e, depois de pedidos insistentes deste para que a turma ficasse quieta, mandou os colegas "calarem a boca". A situação não foi bem recebida por todos, tendo em vista que um dos estudantes se levantou, entre empurrões de carteiras, para encarar o colega, intimando-o a uma briga.

Nenhum dos dois se esquiva do confronto e, um deles, junto à exaltação corporal, reivindica a condição de ser bandido para amedrontar o outro. Ao passo que o colega, na mesma agressividade, provoca-o insinuando que não seria homem suficiente, pois só brigaria se chamasse os amigos. Enquanto um reivindica o bandido como condição de poder, o outro o coloca como covardia, ao atrelá-lo à necessidade de "outros amigos" para defendê-lo. Após intervenção dos demais colegas e do professor, a situação se acalmou e os dois envolvidos, entre resmungos, olhares tortos e caras fechadas, voltaram para seus lugares, sem que qualquer outra menção a uma possível briga fosse feita.

Essa situação, além de mostrar as tensões internas da categoria, indica que o significado do termo bandido se modifica a depender do contexto, da situação e dos atores que o mobilizam e da forma o fazem, possuindo certa plasticidade (Feltran 2010). São os próprios atores que tensionam os significados do termo, em torno do qual as diferenças produzidas são valoradas a partir dos estudantes que o mobilizam e de como eles concebem o "ser bandido" (Zaluar 2015). A demonstração de poder e a revelação da covardia aparecem à medida que são requisitadas pela interação, transparecendo os significados de bandido para cada um deles. No entanto, ambos se revelam propensos a sustentar - mesmo que momentaneamente - uma lógica guerreira de confronto por meio de atos violentos, ao se valerem 
da imposição de um tom de voz elevado, da exaltação dos movimentos do corpo e até mesmo de chutes e empurrões nas carteiras próximas.

Com isso, pretende-se evidenciar que uma série de condições, que não necessariamente estão relacionadas aos conteúdos programáticos das disciplinas e à realidade estritamente educacional, são mobilizadas no processo de construção da experiência desses estudantes no ambiente que é a escola. Nesse processo, muitas vezes, aspectos relacionados ao bairro surgem de forma que estigmatizam esses discentes. No entanto, é justamente por não considerar apenas a repercussão negativa do território sobre o comportamento - tampouco que o território é a única dimensão de interferência - que no próximo tópico pretende-se discutir como a condição juvenil, também decorrente da vivência cotidiana e habitual sobre a região, adentra e se faz existir no espaço escolar, em que bairro, juventude e escola se encontram.

\section{Entre paqueras, brigas e tecnologias: a experiência que vem dos afetos}

A escola, para os estudantes, não é um espaço à parte e descolado da realidade que vivem fora da instituição; ela é mais um espaço onde ocorrem os processos de construção da experiência dos indivíduos, de forma que essas circunstâncias não estão vinculadas nem exclusivamente à condição de ensino, nem somente à territorial, mas se articulam constantemente. Por isso, neste tópico, pretendemos abordar como a condição juvenil e os afetos aparecem na constituição da experiência dos estudantes, na qual o território surge como suporte, em meio ao contexto dos signos e repertórios manejados.

A abordagem a partir da noção da "experiência" é construída em oposição à concepção de que a identidade individual está ligada a um único papel social, o qual constituiria o cerne de cada ser e de suas ações sociais (Dubet 1994). Adotar essa abordagem para tratar dos estudantes se justifica, de um lado, por considerá-los a partir de uma perspectiva ativa, enquanto atores sociais que participam do processo de construção da própria experiência social, sem que seja algo estruturalmente imposto pela sociedade e suas instituições (Mattar 2019). É neste ponto que propomos os afetos e, mais especificamente, a maneira como são manejados e expressados, como categoria para discutir essa apropriação dos estudantes sobre sua própria experiência na escola. De outro lado, considera-se que a condição de estudante é uma, dentre tantas outras, que constituem os atores em questão, tendo em vista o fato de serem também jovens ${ }^{17}$.

Aqui, vale discorrer brevemente sobre como a noção dos "afetos" e a "afetividade" são entendidos neste trabalho. Consideram-se os "afetos" como o resultado do processo cognitivo, social e cultural no qual as emoções são postas em marcha a partir da expressão individual ou coletiva. Nas palavras de Le

17 Considerar a condição de juventude implica em reconhecer tanto que os constitutivos identitários desse grupo já não se restringem à fábrica, aos partidos ou à escola, ou seja, às instituições rigidamente definidas, quanto que se configuram como um grupo heterogêneo e "se definem e organizam em torno de bandeiras, objetos, crenças, estéticas e consumos culturais que variam de acordo com o nível socioeconômico, as regiões, o grau de escolaridade” (Reguillo 1998: 58) e uma série de outros elementos, como a raça, a etnia e o gênero. 
Breton (2012: 72), "o indivíduo interpreta as situações através de um sistema de conhecimento e valores. A afetividade exibida é seu resultado"18.

Com isso, pontua-se duas dimensões importantes para a leitura e justificativa da abordagem dos afetos: são relacionais e estão inseridos em um sistema cultural. Isso implica que as emoções pertencem a um repertório cultural, a partir do qual são sentidas, percebidas e expressadas pelos indivíduos. Ou seja, as emoções estão atreladas a um sistema simbólico, que as torna inteligíveis, reconhecidas e legitimadas por grupos. Dessa forma, não são meras substâncias biológicas, ou restritamente respostas fisiológicas; são resultados de processos cognitivos complexos, que pressupõem uma rede de significados culturais e decorrem de dinâmicas de aprendizado e interpretação sobre a realidade. De tal forma que, pelos signos que as legitimam, as emoções se tornam vetores essenciais da interação, ao informar aos atores sobre os sentimentos mútuos. Assim, "as emoções são modos de filiação a uma comunidade, uma forma de se reconhecer e poder comunicar junto, sobre um fundo emocional próximo" (Le Breton 2012: 73) ${ }^{19}$.

Neste trabalho, são os estudantes que constituem nosso grupo de interesse, a partir da sua condição juvenil. É por intermédio dessa perspectiva que propomos as categorias da paquera, das brigas e das tecnologias para abordar os afetos e a afetividade entre e dos estudantes, por considerar que a noção de juventude se constitui enquanto expressão desse conjunto sensível. A importância dessa condição para este trabalho é pontuar que esses afetos - decorrentes de um sistema de valor vinculado à condição juvenil - aparecem não apenas como vetores da rede de sociabilidade dos estudantes, mas, principalmente, como elementos de atribuição de sentido ao espaço escolar.

A dimensão da paquera surge durante a pesquisa a partir de duas perspectivas principais. Primeiro, por ser uma das temáticas mais presentes nas rodas entre os estudantes, o que mobilizava as conversas e a atuação destes. Segundo, pela suposta contradição de ser uma das condições mais presentes e perceptíveis no Colégio, ao mesmo tempo em que é uma das mais inacessíveis, principalmente se você está fora do circuito de paqueras. Ou seja, se alguém não participa e integra os grupos de atores da paquera, nem maneja e identifica os sinais e signos delas, além de mostrar uma suposta inaptidão a integrá-los, escancara que é um estranho por ali.

A paquera é um grande mobilizador do comportamento e das conversas entre os estudantes no Colégio, no âmbito da qual olhares provocadores, tímidos e constrangidos se deixam escapar, porque muitas vezes a atenção durante a aula está dispersa. Talvez, por isso, o lugar em que os alunos sentem é tão revelador e dinâmico: em uma semana, podem estar junto com os grupos de amigos; em outra, mais próximos dos rrushes $^{20} \mathrm{ou}$, ainda, lado a lado quando a paquera se torna um relacionamento mais sério.

18 Tradução realizada pelas autoras. Na versão original: "El individuo interpreta las situaciones através de su sistema de conocimiento y de valores. La afectividade desplegada es su resultado” (Le Breton 2012: 72).

19 Tradução realizada pelas autoras. Na versão original: "Las emociones son modos de afiliación a una comunidad, una forma de reconocerse y de poder comunicar juntos, bajo un fondo emocional próximo” (Le Breton 2012:73).

20 Termo, emprestado da língua inglesa, que os estudantes utilizam para se referir às pessoas com as quais estão se relacionando brevemente ou a respeito de quem têm interesse em paquerar. O termo crush se diferencia do rolo, pois este segundo já pressupõe a existência de uma relação, mesmo que ainda de maneira inicial ou informal. 
Principalmente nas aulas em que as regras e a dinâmica de sala são mais flexíveis que o tradicionalmente cobrado, com as carteiras em fileiras e os lugares marcados.

A aula de Sociologia, muitas vezes, se encaixa nessa possibilidade, em que os estudantes aproximam as carteiras para assistir às aulas, sem necessariamente seguir os lugares previamente decididos pela coordenação. De forma que, além de impactar um possível roteiro pré-programado pelos professores, a lógica da paquera interfere na dinâmica dos lugares, na maneira como a aula vai transcorrer e até mesmo no fluxo de estudantes que aparecem à porta ou buscam razões para sair da sala e acessar o pátio, ainda que por breves minutos.

A sala de aula, entretanto, não é o único ambiente em que essas interações ocorrem, já que essa atividade permeia todos os espaços escolares. Desde os corredores, durante a troca de professores, até as escadarias dos blocos de salas, quando se gazeia ${ }^{21}$ aula para paquerar, além do pátio, durante o intervalo, momento em que é mais aceita pela Coordenação, mesmo que acompanhada de uma série de restrições e olhares proibitivos. De qualquer forma, o intervalo é o momento em que os grupos desfilam: é a hora de serem vistos, para aqueles mais desinibidos, ou se recolherem, para os mais tímidos.

As garotas, dessa forma, se revezam no espelho do banheiro para arrumar os cabelos e ajustar o uniforme, deixando-o mais rente ao corpo, tanto quanto permitido pelas pedagogas e pela diretora. Entre os garotos, alguns exibem seus bonés e óculos escuros, andando cheios de autoridade pelo pátio; outros permanecem na quadra de futebol e, entre um lance e outro, provocam as garotas na arquibancada, jogando o moletom tirado durante o jogo, dedicando algum lance ou até mesmo iniciando alguma briga entre os outros jogadores ${ }^{22}$.

De fora, a impressão é que todos sabem o que acontece no circuito das paqueras. São os próprios estudantes que contam que o povo do Colégio é assim, não precisa nem de aliança para avisar que alguém começou a namorar e "logo quando sabe [o povo], se joga em cima", evidenciando, de um lado, que a situação de paquera é um dos elementos das conversas e do interesse dos alunos e que todos estão acompanhando o que acontece. Ou seja, há um consenso mínimo entre os signos e o sistema simbólico que constituem esses repertórios. De outro lado, as paqueras também se constituem em jogos de sedução dentro da escola, sobre quem está paquerando quem e sobre os compromissos assumidos. Situação que, em nosso ver, repercutia no fato de alguns estudantes e seus grupos se mostrarem mais ou menos cobiçados nessas relações, o que poderia, inclusive, ser um motivo de briga entre eles. Pois, interessar-se por e seduzir alguém que já se encontrasse em um rolo, mesmo que este não assumisse o compromisso de um namoro, tomava a forma de uma afronta.

As brigas e os confrontos, assim como as paqueras, também apareciam como elementos importantes na constituição da sociabilidade entre os estudantes e, às vezes, até aconteciam por causa destas

21 É um termo e/ou gíria local utilizada para o ato de ausentar-se das aulas para ficar com os amigos e colegas, seja dentro da própria escola, seja nos seus arredores.

22 Um ponto interessante é a forma como as redes de amizades e paqueras entre os estudantes LGBTQIA+ (Lésbicas, Gays, Bissexuais, Transexuais, Queer, Intersexo, Assexual e outros grupos) se instauram, pois há especificidades em relação às estratégias de sedução, presença e embate em relação àquelas manejadas pelos estudantes heterossexuais e, inclusive, particularidades quanto às interações afetivas entre os grupos. Aqui, infelizmente, não trazemos o grau de detalhamento necessário que permita aprofundar satisfatoriamente essa discussão, mas é importante evidenciar que o coletivo de estudantes e suas formas de interação apresentam ainda mais complexidade do que aqui apresentamos. Portanto, há uma limitação da análise proposta em termos de identidade, sexualidade e gênero. 
últimas. Entre as garotas, consistiam em provocações verbais ou olhares por meio dos quais se encaravam, sem que nenhum conflito físico se instaurasse. Mesmo que nenhuma palavra fosse dita entre os grupos, tais condutas não ocorriam sem interações, em que a troca de olhares agressivos e as caras fechadas, seguidas de cochichos e deboches entre as amigas, se impóem. Muitas vezes, como assinalado, eram as próprias paqueras que pautavam os confrontos entre os grupos de alunas, quando não era raro ouvir a justificativa de que "se ela continuar dando em cima do meu homem vai ter briga". Essa situação se assemelha às formas de confronto entre os estudantes LGBTQIA+, inclusive em termos de aproximação em redes de amizades com as garotas.

Diferente do que acontecia com os garotos, entre os quais os confrontos físicos pareciam mais latentes e as motivações eram diversas, desde paqueras até confusões com grupos distintos, de fora do Colégio. Pelas brigas, era possível perceber os coletivos de afinidades e amizades: no caso dos confrontos físicos, os amigos mais próximos logo se juntavam para ajudar os protagonistas, o que formava aglomerações no pátio, que só se dispersavam com a chegada das inspetoras e pedagogas. Momento em que as brigas cessavam e os alunos, num acordo coletivo instantâneo, passavam a negar o ocorrido, o que também demostra a formação de grupos de afinidade e noções de pertencimento variáveis de acordo com as relações e interações que surgem. Dessa forma, tal qual ocorria com as paqueras, o que se percebia é que nem todos os atores escolares tinham acesso às informações sobre as razões para que as brigas acontecessem; em nosso caso, na maioria das vezes, era preciso esperar algumas aulas para que os motivos da confusão começassem a aparecer e os estudantes mais próximos se sentissem confortáveis para nos atualizar dos ocorridos.

O que nos interessa pontuar é que, além das paqueras e das brigas estarem inseridas em uma rede de signos e valores atrelados à condição de jovens desses estudantes, no interior da qual a forma de usar o boné, arrumar o cabelo, amarrar a camiseta do Colégio para ajustá-la ao corpo, usar ou deixar de usar uniforme e tantos outros detalhes no vestir-se, andar e falar, etc., compõem um modo de comportamento reconhecido pelo grupo, inserido numa lógica dos afetos. Os afetos constroem a rede de sociabilidade desses jovens, sendo manejados dentro desse sistema simbólico, o qual, muitas vezes, mesmo que não de forma restrita e exclusiva, articula-se com a dimensão territorial.

Dessa forma, faz parte do repertório da paquera a troca de olhares, a sedução, mas também a expressão agressiva de uma suposta vantagem ou o controle sobre uma paquera, como expresso na fala "se ela continuar... vai ter briga". Assim como a referência ao termo bandido, discutida anteriormente. Fazê-la implica usar os signos e valores imbricados no grupo e na região, a partir do repertório afetivo que tal condição significa. Ou seja, ao trazer a noção de bandido, muitas vezes, os estudantes querem se mostrar uns aos outros enquanto homens fortes e corajosos ou outras características que estejam inseridas nesse repertório afetivo e cultural. Trata-se de marcar uma posição dentro desse circuito por meio do afeto e mais: significa pôr em prática a habilidade de manejar as emoções em razão do que se quer mostrar sobre si mesmo (Le Breton 2012).

Essa dinâmica exige a referência a um contexto específico de interações e acontece a todo momento, na forma pela qual os estudantes pretendem se mostrar aos outros, ora como sedutores, tímidos e sensíveis, ora como bravos, agressivos e seguros, revelando um jogo de forças e de poder a partir dos 
afetos. A essa altura, questiona-se até que ponto o território se articula com a dimensão dos afetos. Aparentemente, o território surge como contexto em que essa rede simbólica se referência, proporcionando signos e valores que dão bases aos significados e ao repertório afetivo mobilizado.

Nessa discussão, o uso da tecnologia surge como instrumento importante da forma como as relações e interações são estabelecidas no Colégio. Essa condição será abordada, principalmente, em relação ao acesso à internet e à utilização de telefones celulares, que são elementos presentes no cotidiano de forma bastante intensa, seja para interagir nas redes sociais como o Instagram e trocar mensagens pelo Whats $A p p^{23}$, seja a partir das funções acessadas nos próprios celulares, como fotos e músicas. $\mathrm{O}$ que muitas vezes pode se configurar como um grande desafio para o andamento da aula, tendo em vista que o uso de fones de ouvidos, por exemplo, é atitude constante entre eles, mesmo durante uma conversa.

Para a maioria dos professores ou gestores, as tecnologias se constituem em um dos grandes problemas contemporâneos da escola e motivo da falta de atenção dos estudantes, que estão mais interessados em mexer nesses aparelhos do que prestar atenção dos conteúdos da aula. Já para os estudantes, o uso dos aparelhos celulares e da internet é um dos principais elementos de sociabilidade, sendo tão requisitado entre eles, que uma prática habitual é a venda da senha do $W i$-Fi destinada aos funcionários (professores, secretaria, direção e coordenação pedagógica), em preços que podem variar de $\mathrm{R} \$ 5,00$ a $\mathrm{R} \$ 10,00^{24}$. É possível obter a isenção desse valor entre amigos muito próximos ou, no caso de uma paquera em andamento, em que o acesso ao Wi-Fi se constitui como moeda de troca e privilégio diante dessas relações, tendo em vista que é sinal de grande parceria ou interesse (Mattar 2019).

Autores como Green e Bigum (1998) argumentam que a juventude tem se tornado pioneira na exploração dos modos de vida e das interações pautados em relações digitais e virtuais a partir da tecnologia, mesmo que reconheçam que tais condições sociais não se restrinjam apenas às culturas juvenis. Em termos escolares, Pereira (2010) enfatiza a dimensão geracional que pauta as relações nesse ambiente, em que professores, gestores e alunos operam a partir de lógicas de ação distintas, as quais muitas vezes se integram a partir de tensões nesse espaço. De um lado, os dois primeiros segmentos valorizam concepções de ordem, respeito às regras institucionais e disciplina; de outro, o terceiro grupo valoriza a diversão imediata e o confronto à tais regras.

Nessa perspectiva, Green e Bigum (1998) abordam os jovens na escola a partir da figura do "alienígena de sala de aula”. Com isso, buscam enfatizar os comportamentos contemporâneos juvenis vinculados às mídias e redes digitais e virtuais de comunicação, que são cada vez mais um dos componentes do processo de interação e interpretação do mundo, ao mesmo tempo em que são vistos com reticência e resistência por parte dos professores e gestores, quando presentes no ambiente escolar.

23 O primeiro é uma rede social on-line que permite o compartilhamento de conteúdos de mídia em vídeo, foto e texto a todos os usuários do aplicativo ou a grupos restritos de seguidores, além da troca privada/particular de mensagens, e o segundo serve, basicamente, como meio de troca privada/particular desses conteúdos de mídia por meio de mensagens instantâneas via internet entre os contatos ou grupos previamente criados.

24 Essa situação exige, de tempos em tempos, uma reação dos gestores do Colégio, sendo necessária a troca de senha com frequência, pois, devido ao número de acessos, a rede fica sobrecarregada e mais lenta, inviabilizando o uso. Foi justamente em um dia no qual a rede da internet estava sobrecarregada e causando grandes aborrecimentos aos gestores que fomos alertadas, em meio a desabafos e reclamações, sobre a existência dessa prática. Das estratégias para conseguir essa informação, a mais efetiva parecia ser a proximidade familiar entre estudantes e funcionários da secretaria, seja na obtenção direta entre pais e filhos, seja por meio de um irmão mais novo que, ao acompanhar o expediente de trabalho, obtém o acesso como forma de distração. De toda forma, por parte dos estudantes, pouco se contava sobre isso. 
No caso dos estudantes, a forma como usam as tecnologias não se restringe a reforçar vínculos já construídos entre os atores, mas também demostrar para os colegas seus grupos de pertencimento e interação. Exemplos disso, são as selfies, imagens tendo a figura de si próprios como centro, capturadas constantemente e, quando possível, postadas imediatamente nas redes sociais.

Nesses momentos, as relações de proximidade eram demonstradas e reforçadas, tanto a partir de brincadeiras afetivas e elogios, da paquera - pois as interações tecnológicas também eram utilizadas como recursos de aproximação nesse circuito - quanto de zoações ${ }^{25}$. Daí a grande procura pela senha da rede de $W i$-Fi do Colégio, tendo em vista que a maioria dos estudantes possuía o plano de internet móvel pré-pago ou sem dados de navegação suficientes para usá-lo de forma imoderada.

Dessa forma, os estudantes usam a tecnologia, principalmente através da internet, para levar à sala de aula os elementos que constituem a cultura juvenil fora desse espaço. $\mathrm{O}$ ritmo das músicas de funk e rap que ocupam cotidianamente os espaços da escola, ao soarem nos celulares ou ainda se fazerem presentes nas danças e passinhos coreografados, são exemplos de como essa condição emerge e é acionada a cada brecha entre as formalidades das aulas.

Não são à toa o gênero musical e o arsenal mobilizados, tendo em vista que, muitas vezes, vêm carregados de expressões de pertencimento e identidade entre grupos e, especificamente, naquele grupo de estudantes. A música aparece como expressão importante da cultura juvenil no ambiente escolar, e os pedidos do Grêmio estudantil em anos anteriores para que pudessem tocá-las no intervalo reflete essa condição. Assim como a negativa vinda da coordenação, que atribui à presença da música possíveis desordem e caos. Pereira (2010), a partir da categoria das zoeiras, sustenta a tese de que essas relações de brincadeiras e provocações feitas pelos e entre os estudantes são uma forma de tentar impor o seu ritmo frente ao ritmo escolar.

Nesse sentido, o autor ressalta e justifica que boa parte dos elementos que formam as redes de sociabilidade dos estudantes são reconhecidos, muitas vezes, pelo corpo docente e coordenações como indisciplina, desrespeito e desinteresse (Pereira 2010, 2016), sendo limitada a essa compreensão a condição de aluno que se sobressai (Mattar 2019). No entanto, se, de um lado, o uso da tecnologia marca um modo de ser jovem, constituindo-se inclusive em importante elemento de sociabilidade, de outro, muitas vezes, é o componente afetivo que mobiliza essa rede de convivências e a insere numa trama de significados: paquerar, pertencer, brigar, confrontar, ouvir música e dançar, entre tantas outras formas de manejar os afetos, a partir das relações em que se está inserido.

O que nós pretendemos é demonstrar que certos comportamentos dos estudantes dentro do Colégio decorrem de sua condição juvenil, eis que se constituem como elementos manejados por eles enquanto jovens, para construir suas redes e laços de sociabilidade. Nesse sentido, o Colégio se coloca como um dos espaços privilegiados do encontro e da interação de diversos modos de ser jovem. Porém, mais que isso, trazemos a dimensão do afeto e, com isso, buscamos associar esse modo de ser jovem também com uma forma de sentir e interpretar o mundo ao seu redor.

25 Esses comportamentos chegavam inclusive a abranger nossa relação com eles, pois não era raro que os estudantes mais próximos pedissem para tirar selfies conosco. 
As emoções não são apenas processos fisiológicos, são também interações e, portanto, produto de processos sociais e culturais. A expressão dessas emoções se materializa em um conjunto de signos demostráveis e interpretáveis aos outros (Le Breton 2012). De forma que os afetos estão impregnados de significados, sendo elementos potenciais para a interpretação de como os jovens atribuem sentido à experiência escolar.

Trata-se de observar o caráter social das emoções e a importância dos contextos culturais nas formas de experimentar o sentir afetivamente e, aqui, a dimensão territorial pode ser articulada, justamente, por se configurar como contexto dessa rede simbólica. Ou seja, a partir do território, têm-se os signos e valores que constituem a base de significados do repertório afetivo que norteia as relações e interações entre os atores sociais. Por isso, pensar a escola e a experiência desses sujeitos implica em questionamentos sobre que escola é essa que está sendo vivenciada, material, subjetiva e cognitivamente e quem são esses estudantes.

\section{Considerações finais}

A presente problematização se desenvolveu com a finalidade de propor que a experiência dos estudantes na escola não é decorrente e determinada apenas pelo sistema educacional propriamente dito ou pela constituição do indivíduo em relação a um único papel social decorrente deste: o de aluno. Nesse sentido, argumenta-se que uma série de elementos como a paquera, as brigas e os confrontos, a música que escutam, os estilos de vestir, os esportes, atividades que praticam, os modos como sentem e outros elementos que integram a sociabilidade dos jovens são articulados e mobilizados por eles para atribuir sentidos às suas práticas sociais e experiências na escola, assim como o local de residência e as valorações simbólicas que são atribuídas aos territórios, estejam no centro ou na periferia, como nas Vilas e quebradas (Pereira 2010).

Longe de uma análise rígida e fixa, propomos uma interpretação da experiência dos estudantes a partir da articulação entre os conceitos de estigma e afeto. Sob essa luz, o processo de estigmatização desses jovens em relação às condições sociais e territoriais da região em que moram e estudam se vincula e divide espaço com o processo de atribuir sentido à escola, por meio de um potencial sociabilidade dos afetos.

De forma que, de um lado, os estigmas incorporados pelos estudantes e impostos a eles são reflexos das condições de desigualdades sociais e de formas de demarcar tal condição nesses sujeitos, bem como de valorar negativamente a escola. De outro lado, os afetos se mostram como elementos importantes na construção das redes de sociabilidade, mas também, ao constituí-la, tornam-se elemento de significação da escola e das relações que ali ocorrem, como uma forma de apropriação daquele espaço pelos estudantes. Assim, estigma e afeto se intercalam, se sobrepõem e se articulam nesse caminho percorrido pelos estudantes em vivenciar a escola e construir uma experiência nesse ambiente.

$\mathrm{O}$ argumento central é que esse processo de atribuição de sentido ocorre a partir das relações e interações entre os indivíduos, considerando as maneiras em que tais grupos manejam os signos e va- 
lores do repertório cultural em que estão inseridos, seja em termos territoriais, afetivos ou juvenis. Por fim, questiona-se: se não a experiência desses jovens, o que, afinal, daria sentido à escola?

Kamille Brescansin Mattar é Doutoranda e Mestra em Sociologia pela Universidade Federal do Paraná (UFPR). Bolsista CAPES - DS.

Maria Tarcisa Silva Bega é Doutora em Sociologia pela Universidade de São Paulo (USP) e Professora Titular da Universidade Federal do Paraná (UFPR).

\section{REFERÊNCIAS BIBLIOGRÁFICAS}

Andrade, Luciana Teixeira e Leonardo Souza Silveira. 2013. "Efeito-território: explorações em torno de um conceito sociológico". Revista Civitas 13(2): 381-402. doi: https://doi.org/10.15448/19847289.2013.2.14295

Belmiro, Luís e Maria Tarcisa Silva Bega. 2018. “Desigualdade social e o processo de urbanização de Curitiba: o caso do Jardim Parque Iguaçu”. Tempo da Ciência 25: 147-161. doi: https://doi. org/10.48075/rtc.v25i 49.20038

Belmiro, Luís. 2019. Da lama ao caos: a urbanização de Curitiba vista do Bolsão Audi-União. Tese de Doutorado. Programa de Pós-Graduação em Sociologia, Universidade Federal do Paraná. Disponível em: https://acervodigital.ufpr.br/handle/1884/66413

Brandalize, Nina Melh. 2017. Uberaba e suas histórias. Curitiba: Imprensa Oficial do Estado do Paraná.

Caldeira, Teresa. 2000. Cidade de muros. São Paulo: Editora 34.

Dubet, François. 1994. Sociologia da Experiência. Lisboa: Instituto Piaget.

Durham, Eunice. 2004 [1986]. “A sociedade vista da periferia”. In: A dinâmica da cultura: ensaios de antropologia. São Paulo: Cosac Naify.

Feltran, Gabriel. 2010. "Periferias, direito e diferença: notas de uma etnografia urbana”. Revista de Antropologia 53(2): 565-610. doi: https://doi.org/10.11606/2179-0892.ra.2010.37711

Frúgoli Jr, Heitor. 2005. “O urbano em questão na Antropologia: interfaces com a Sociologia”. Revista Antropologia 48(1): 133-165. doi: https://doi.org/10.1590/S0034-77012005000100004 
Goffman, Erving. 1982. Estigma: notas sobre a manipulação da identidade deteriorada. Rio de Janeiro: Zahar.

Kowarick, Lúcio. 2009. "Produção do espaço urbano e lutas sociais”. In: Escritos Urbanos. São Paulo: Editora 34.

Le Breton, David. 2012. "Por una antropología de las emociones". Revista Latinoamericana de Estudios Sobre Cuerpos, Emociones y Sociedad 10 (4): 69-79. Disponível em: http://www.relaces.com.ar/ index.php/relaces/article/view/208/145

Lefebvre, Henri. 2006 [1974]. A produção do espaço. Trad. Doralice Barros Pereira e Sérgio Martins. Paris: Editions Antropos.

Magnani, José Guilherme. 2003. “A antropologia urbana e os desafios da metrópole”. Tempo Social 15(1): 81-95. doi: https://doi.org/10.1590/S0103-20702003000100005.

Mattar, Kamille Brescansin. 2019. Entre Vilas: a sociabilidade juvenil como produtora de sentidos em um Colégio na periferia de Curitiba. Dissertação. Programa de Pós-Graduação em Sociologia, Universidade Federal do Paraná. Disponível em: https://acervodigital.ufpr.br/handle/1884/62770?show=full

Mayol, Pierre. 2013 [1994]. "Primeira parte: morar por Pierre Mayol”. In A invenção do cotidiano: morar, cozinhar. v. 2., org. M. de Certeau. Petrópolis: Editora Vozes.

Pereira, Alexandre Barbosa. 2010. "A maior zoeira”: experiências juvenis na periferia de São Paulo. Tese de Doutorado. Programa de Pós-Graduação em Antropologia Social, Universidade de São Paulo.

Pereira, Alexandre Barbosa. 2016. "A Juventude como questão: alteridade e autoridades em escolas da periferia de São Paulo”. Revista Anthropológicas 27(1): 102-131. doi: https://doi.org/10.1590/2175623654713

Poker, José Geraldo. 2013. “Os sentidos de compreensão nas teorias de Weber e Habermas”. Revista Trans/Form/Ação 36(1): 221-244. doi: https://doi.org/10.1590/S0101-31732013000400014

Reguillo, Rossana. 1998. "El año dos mil, ética, política y estéticas: imaginarios, adscripciones y prácticas juveniles. Caso mexicano". In: "Viviendo a toda". Jóvenes, territorios culturales y nuevas sensibilidades, org. M. Margulis et al. Santa Fé de Bogotá: Universidad Central,Siglo del Hombre Editores.

Santos, Milton. 2006. “A força do lugar”. In: A natureza do espaço: técnica e tempo, razão e emoção. São Paulo: Editora da USP. 
Santos, Milton. 2005. "O retorno do território". OSAL: Observatorio Social de América Latina 6 (16): 252-261. Disponível em: http://bibliotecavirtual.clacso.org.ar/ar/libros/osal/osal16/D16Santos.pdf

Santos, Viviane Vidal Pereira dos. 2017. Viver em condominios verticais do programa "Minha Casa, Minha Vida" na periferia de Curitiba-PR: pós-ocupação, trajetórias e sociabilidade. Dissertação de Mestrado. Programa de Pós-Graduação em Sociologia, Universidade Federal do Paraná. Disponível em: https://acervodigital.ufpr.br/handle/1884/48936?show=full

Silva, Madianita Nunas da. 2014. "Produção dos espaços informais de moradia na metrópole de Curitiba”. Revista Mercator 13(1): 63-78. doi: https://doi.org/10.4215/rm2014.1301.0005

Schmid, Christian. 2012. "A teoria da produção do espaço de Henri Lefebvre: em direção a uma dialética tridimensional". GEOUSP - Revista Espaço e Tempo 32: 89-109. doi: https://doi. org/10.11606/issn.2179-0892.geousp.2012.74284

Taylor, Charles. 2010. Imaginários sociais modernos. Lisboa: Edições Texto \& Grafia.

Telles, Vera. 2015. “Cidade: produção de espaços, formas de controle e conflito”. Revista de Ciências Sociais 46 (1): 15-41 Disponível em: http://www.periodicos.ufc.br/revcienso/article/view/2423

Wautier, Anne Marie. 2003. "Para uma Sociologia da Experiência. Uma Leitura Contemporânea: François Dubet”. Revista Sociologias 09: 174-214. doi: http://dx.doi.org/10.1590/S151745222003000100007

Zaluar, Alba. 2004. "Masculinidades, crises e violências”. In: Integração perversa: pobreza e tráfico de drogas. Rio de Janeiro: Editora FGV. 


\title{
ENTRE ESTIGMAS E AFETOS: A EXPERIÊNCIA ESCOLAR DE JOVENS EM UMA PERIFERIA DE CURITIBA-PR
}

Resumo: Este trabalho é resultado de pesquisa empírica, baseada em observação participante e realizada em escola da rede pública estadual em Curitiba, Paraná. De forma geral, pretende-se discutir a experiência dos jovens em termos escolares. A hipótese é que essa experiência é marcada pelas condições territoriais e sociais em que a escola está inserida: uma periferia. Por isso, pergunta-se se a condição de periferia da região repercute nas experiências dos estudantes. As interações no interior da escola e com a região se constituem nos objetos centrais, a partir dos quais defendemos que, de um lado, esta experiência é estigmatizante; de outro, é afetiva. Nesse sentido, argumenta-se que o processo de estigmatização se vincula e divide espaço com o processo de atribuir sentido à escola, por meio de uma potencial sociabilidade dos afetos. Por fim, questiona-se: se não a experiência desses jovens, o que, afinal, daria sentido à escola?

Palavras-chave: Sociologia Urbana; Juventude; Experiência escolar; Efeito-território; Afetos.

\section{BETWEEN STIGMAS AND AFFECTIONS: THE SCHOOL EXPERIENCE OF STUDENTS IN A PERIPHERY OF CURITIBA -PR}

\begin{abstract}
This paper is the result of empirical research carried out in a public school in the city of Curitiba, Paraná State, Brazil, based in participant observation. In general, it intends to discuss the experience of young people in the school environment. Our hypothesis is this experience appears marked by the territorial and social conditions in which the school is inserted: a periphery. Therefore, the article questions if the condition of the region's periphery affects the students' school experiences. Interactions within the school and with the region are the central objects, from which we defend that, on the one hand, this experience is stigmatizing; on the other, it is affective. Thus, it is argued the stigmatization process is linked and divides space with the process of the school significance, through a potential sociability of affections. Finally, if not by the student experience, what could construct the school meaning?
\end{abstract}

Key-words: Urban Sociology; Youth; Social Experience; Territory effect; Emotions.

RECEBIDO: $01 / 06 / 2020$

APROVADO: $21 / 12 / 2020$ 